JURNAL TENGKAWANG (2019)

Vol. 9 (1) : 1 - 13

\title{
EKSTRAK BUAH BAKAU Rhizophora mucronata Lamk SEBAGAI PEWARNA ALAMI PADA KAIN KATUN
}

(Fruit extracts of mangrove Rhizophora mucronata Lamk as a natural coloring agent to cotton)

\author{
Tasya Nabilla Septiandini dan Muflihati \\ Fakultas Kehutanan Universitas Tanjungpura Jalan Imam Bonjol Pontianak 78124 \\ Email: tasyanabilla@student.untan.ac.id
}

\begin{abstract}
The fruit of Rhizophora mucronata Lamk content of tannin which can be used as natural dye color. Research purposes was to extract the fruit of $R$. mucronata, used the extract with fixation material as cotton natural dye, and evaluation the resistance of the color. The research was conducted for three months at Wood Technology laboratory and Wood workshop laboratory at Forestry Faculty Tanjungpura University. The fruit of $R$. mucronata was extraction with aquades with ratio 1:10 (weight/volume) at temperature $\pm 80^{\circ} \mathrm{C}$ for 60 minutes. The fixation materials were tawas, kapur tohor and tunjung. The cotton was dipped into the extract then analyzes the change of the color before and after the coloring process. After that the cotton was dipped into the fixation materials. The ratio of fixation materials and aquades was 1:20 (weight/volume). After coloring the change of the color was measured. Evaluation the resistance of the color after fixation was made refer on ASTM D 870-02-2002 for hot water treatment and ASTM D-1308-02-2013 for cold water treatment. The quality of color was measured with Munsell Soil Color Chart and Hunter Lab. The result of research showed that extract of $R$. mucronata give a pink color to the cotton with average value of $\Delta E$ was 22.74 . The retention of extract to cotton was $4.47 \mathrm{~g} / \mathrm{cm}^{3}$. The additional of fixation materials, i.e. tunjung and kapur tohor resulted the drak color meanwhile tawas made the lightest color. The average $\Delta E$ values were 6.16-39.84. Extract of fruit of $R$. mucronata with additional of tunjung as fixation materials can be used for natural dye for cotton and wood.
\end{abstract}

Keywords : kapur tohor, natural dye, Rhizophora mucronata, tawas, tunjung

\section{PENDAHULUAN}

Negara Indonesia memiliki hutan mangrove terluas di dunia yang mencapai 3 juta ha atau sekitar $19 \%$ dari luas hutan mangrove di dunia. Salah satu hutan mangrove di Indonesia terletak di Kelurahan Setapuk Besar, Kecamatan Singkawang Utara, Kota Singkawang, Provinsi Kalimantan Barat yang di kelola oleh Perkumpulan Swadaya Peduli Mangrove. Sejumlah jenis tanaman mangrove yang terdapat di Kelurahan Setapuk Besar, antara lain Rhizophora mucronata, Rhizophora apiculata, Ceriops decandra, Avicennia marina, Sonneratia caseolaris, Bru guiera cylindrica, Avicennia lanata, Hibiscus tillaceus, Excoecaria agal locha, Nypa fruticans dan Terminalia catappa. Luas tanaman mangrove di Kelurahan Setapuk sebesar \pm 26,1 ha (BLHKS, 2015). Jenis R.mucronata menempati lahan tanaman terluas yaitu sekitar $60 \%$ dari keseluruhan hutan mangrove, tetapi relatif belum banyak diketahui nilai tambahnya selain sebagai pelindung pantai dari abrasi. Penanaman jenis R.mucronata di Kelurahan Setapuk Besar dalam kegiatan rehabilitasi pesisir mengguna kan propagul bagian hipokotil dan dari kegiatan 
penanaman tersebut meninggalkan buah bakau bewarna coklat yang tidak terpakai. Menurut Kwartiningsih, dkk (2013) buah R.mucronata mengandung zat warna alami berupa tanin sebesar 4,326 mg, yang diekstrak menggunakan aquades. Tanin merupakan salah satu komponen senyawa kimia yang dapat dimanfaat kan sebagai pewarna alami tekstil terutama pada kain katun (Mukhlis, 2008).

Katun merupakan salah satu jenis serat alam yang berasal dari tumbuhan digunakan sebagai bahan baku industri tekstil. Kain katun merupakan kain yang berasal dari serat kapas dimana kandungan utamanya adalah selulosa. Kain katun sangat populer karena memiliki sifat menguntungkan seperti kuat dalam keadaan basah, dapat menyerap air (higroskopis), tahan panas dan lembut. Kain katun merupakan jenis kain mempunyai sifat mudah menyerap bahan alami maupun kimia. Struktur kimianya merupakan senyawa benzena yang mengandung gugus hidroksil yang mudah menyerap air, sebagian besar terdiri dari selulosa (Suheryanto, 2013).

Penggunaan zat pewarna alami dibandingkan dengan pewarna sintetis memiliki kekurangan, antara lain pewarnanya yang lemah, konsentrasi dan stabilitas pigmen rendah, keseragaman warna kurang baik dan kurang tahan lama. Salah satu upaya untuk memperkecil kekurangan tersebut dapat dilakukan proses fiksasi. Proses fiksasi pada prinsipnya adalah mengkondisikan zat pewarna yang telah terserap dalam waktu tertentu agar terjadi reaksi antara bahan yang diwarnai, dengan zat warna dan bahan yang digunakan untuk fiksasi
(Lailia dkk, 2014). Tujuan dari proses fiksasi adalah meningkatkan kemampuan menempelnya bahan pewarna, dan meningkatkan ketahanan luntur serta penguat warna dan meningkatkan daya tarik zat warna alam terhadap bahan agar menghasilkan kerataan dan ketajaman warna yang baik. Bahan yang biasa digunakan untuk fiksasi adalah tawas, kapur dan tunjung (Ruwana, 2008). Penelitian bertujuan untuk melakukan ekstraksi buah $R$. mucronata sebagai pewarna alami pada kain katun dengan penambahan bahan fiksasi dan menguji kelunturan warnanya.

\section{METODE PENELITIAN}

Penelitian dilaksanakan di Laboratorium Teknologi Kayu dan Wood Workshop Fakultas Kehutanan Universitas Tanjungpura Pontianak selama lebih kurang 3 bulan.

Bahan yang digunakan adalah limbah buah bakau Rhizophora mucronata Lamk yang berasal dari sisa rehabilitasi lahan di Hutan Mangrove Kelurahan Setapuk Besar Kota Singkawang Kalimantan Barat, kain katun jenis prima, aquades, tawas $\left(\mathrm{KAl}\left(\mathrm{SO}_{4}\right)_{2} .12 \mathrm{H}_{2} \mathrm{O}\right)$, kapur tohor $\left(\mathrm{CaCO}_{3}\right)$ dan tunjung $\left(\mathrm{FeSO}_{4}\right)$. Alat yang digunakan adalah hammer mill, mesh screen 40/60, water bath, notebook computer, scanner HP DJ 2135, munsell soil color chart 2000.

\section{Persiapan Bahan}

Kain katun dicuci bersih mengguna kan aquades, ditiriskan selama 24 jam dan dipotong dengan ukuran $10 \times 10 \mathrm{~cm}$, selanjutnya kain katun di timbang sebagai data berat sebelum direndam $\left(\mathrm{W}_{0}\right)$. Kemudian dilakukan penilaian warna secara kualitatif dengan meng gunakan 
Munsell Soil Color Chart (2000) dan diukur warna awal pada kain katun menggunakan Flatbed Scanner HP DJ 2135 diprogram dengan software adobe photoshop CS 6 yang akan menghasilkan nilai $L^{*}, a^{*}$ dan $b^{*}$ (Hunter, 2008).

\section{Pembuatan larutan pewarna}

Pembuatan larutan pewarna mengacu kepada Kwartiningsih, dkk (2013) dengan modifikasi. Bagian yang diambil untuk diekstrak menjadi larutan pewarna adalah bagian buahnya (Gambar 1b), sedangkan hipokotilnya ditanam untuk kegiatan rehabilitasi lahan (Gambar 1a). Buah yang telah dipisahkan dari hipokotilnya dibersih kan dan dikeringkan, selanjutnya dibuat serbuk dengan hammer mill dan disaring dengan ukuran lolos 40 mesh tertahan 60 mesh lalu diukur kadar airnya. Serbuk buah R.mucronata ditimbang dengan perbandingan 1:10 (b/v) dan direbus dengan menggunakan aquades pada suhu $\pm 80^{\circ} \mathrm{C}$ selama 60 menit, kemudian di saring dan didinginkan selama 30 menit, larutan pewarna siap digunakan. Buah R. mucronata disajikan pada Gambar 1 .

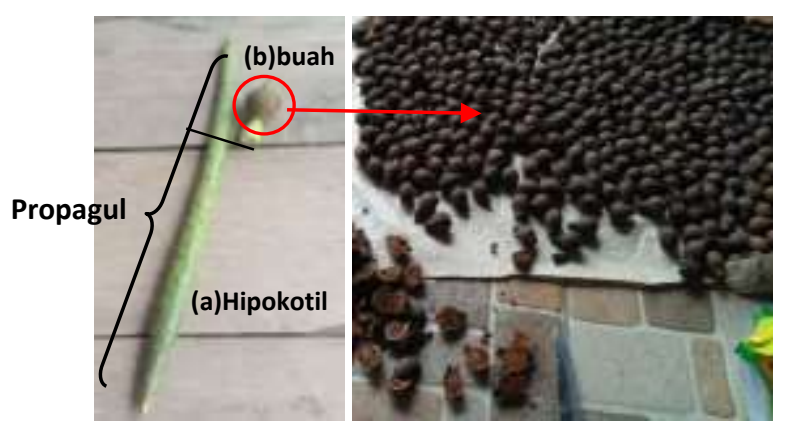

Gambar 1. Propagul Rhizophora mucronata (a) Bagian hipokotil (b) Buah yang digunakan sebagai bahan pewarna (The propagul of Rhizophora mucronata (a) hypocotile (b) fruit for natural dye)

\section{Kadar Ekstrak}

Kadar ekstrak larutan pewarna dari buah R.mucronata dapat dihitung menggunakan rumus :

$$
\mathrm{KE}(\%)=\frac{\mathrm{Wa}}{\mathrm{Wb}-\mathrm{KA}} \times 100 \%
$$

Keterangan:

$$
\begin{aligned}
& \mathrm{KE}=\text { Kadar Ekstrak }(\%) \\
& \mathrm{Wa}=\text { Berat padatan ekstrak }(\mathrm{g}) \\
& \mathrm{Wb}=\text { Berat serbuk }(\mathrm{g}) \\
& \mathrm{KA}=\text { Kadar Air serbuk }(\%) \\
& \text { Pewarnaan Kain Katun }
\end{aligned}
$$

\section{Pewarnaan Kain Katun}

Kain katun direndam di dalam
ekstrak larutan pewarna buah
R.mucronata selama 24 jam,
selanjutnya diangkat dan ditiriskan

selama 24 jam. Kemudian kain katun di timbang sebagai data berat sesudah direndam $\left(\mathrm{W}_{1}\right)$.

Penilaian warna secara kualitatif dilakukan menggunakan Munsell Soil Color Chart (2000) dan diukur perubahan warna menggunakan Flatbed Scanner HP DJ 2135 diprogramkan mengunakan software Adobe Photoshop CS 6 yang akan menghasilkan nilai $L^{*}$, $a^{*}$ dan $b^{*}$ (Muflihati, 2014).Untuk mengetahui banyaknya zat pewarna yang terserap ke dalam kain, dapat dihitung nilai retensinya dengan rumus sebagai berikut : 


$$
\mathrm{R}=\frac{\mathrm{W} 1-\mathrm{W} 0}{\mathrm{~V}} \times 100 \%
$$

Keterangan:

$$
\begin{array}{ll}
\mathrm{R} & =\text { Retensi }\left(\mathrm{g} / \mathrm{cm}^{3}\right) \\
\mathrm{W} 0 & =\text { Berat sebelum direndam }(\mathrm{g}) \\
\mathrm{W} 1 & =\text { Berat sesudah direndam }(\mathrm{g}) \\
\mathrm{V} & =\text { volume kain katun }\left(\mathrm{cm}^{3}\right)
\end{array}
$$

\section{Proses Fiksasi}

Bahan fiksasi berupa tawas, tunjung dan kapur tohor masing-masing dilarutkan ke dalam aquades dengan perbandingan 1:20 (b/v), sampai larutannya mengendap (Fitrihana, 2007). Larutan yang bening diambil dan digunakan untuk merendam kain katun yang sudah diwarnai selama 10 menit, setelah itu kain katun dicuci bersih menggunakan aquades dan ditiriskan selama 24 jam. Penilaian warna secara kualitatif dilakukan pada kain katun setelah difiksasi menggunakan Munsell Soil Color Chart (2000) dan diukur perubahan warna menggunakan Flatbed Scanner HP DJ 2135 diprogramkan mengunakan software Adobe Photoshop CS 6 yang akan menghasilkan nilai $L^{*}, a^{*}$ dan $b^{*}$ (Muflihati, 2014).

\section{Pengujian Kelunturan Kain Katun}

\section{a. Pengujian kelunturan warna dengan air panas (ASTM D 870- 02-2002)}

Pengujian air panas dilakukan dengan merendam kain katun ke dalam air panas pada suhu $38 \pm 2{ }^{\circ} \mathrm{C}$ selama 1 jam. Setelah itu kain katun diangkat, ditiriskan selama 24 jam. Penilaian warna kain katun setelah uji luntur secara kualitatif dilakukan mengguna kan Munsell Soil Color Chart (2000) dan diukur perubahan warna menggunakan Flatbed Scanner diprogramkan mengunakan software Adobe Photoshop CS 6 yang akan menghasilkan nilai $L^{*}, a^{*}$ dan $b^{*}$ (Muflihati, 2014).

\section{b. Pengujian kelunturan warna dengan air dingin (ASTM D- 1308-02-2013)}

Kain katun direndam dalam aquades (suhu ruang) selama 1 jam. Setelah itu sampel diangkat dan ditiris kan selama 24 jam. Penilaian warna secara kualitatif dilakukan mengguna kan Munsell Soil Color Chart (2000) dan diukur perubahan warna menggunakan Flatbed Scanner diprogramkan mengunakan software Adobe Photoshop CS 6 yang akan menghasilkan nilai $L^{*}, a^{*}$ dan $b^{*}$ (Muflihati, 2014).

Penilaian kualitas warna secara kuantitatif dilakukan menggunakan nilai $L^{*}, a^{*}$ dan $b^{*}$ pada ruang warna CIELab. Pengaruh perbedaan nilai berdasarkan nilai $\Delta \mathrm{E}$ dari rumus Hunter (2008) sebagai berikut:

$$
\Delta \mathrm{E}=\sqrt{(\Delta L *)^{2}+(\Delta a *)^{2}+(\Delta b *)^{2}}
$$

Keterangan:

$\Delta \mathrm{E}=$ Perbedaan Warna

$\Delta \mathrm{L}^{*}=$ Perbedaan kecerahan $=\mathrm{L}^{*}$ contoh uji - L*kontrol

$\Delta a^{*}=$ Perbedaan merah atau hijau $=$ $a^{*}$ contoh uji $-a^{*}$ kontrol

$\Delta b^{*}=$ Perbedaan kuning atau biru $=$ $b^{*}$ contoh uji $-b^{*}$ kontrol

Pengaruh perbedaan nilai $\Delta \mathrm{E}$ disajikan pada Tabel 1. 
Tabel 1. Pengaruh perbedaan nilai $\Delta \mathrm{E}$ (influence of value differences of $\Delta \mathrm{E}$ )

\begin{tabular}{cc}
\hline Perbedaan Warna $(\Delta \mathrm{E})$ & Pengaruh \\
\hline$<0,2$ & Tidak terlihat \\
$0,2-1,0$ & Sangat kecil \\
$1,0-3,0$ & Kecil \\
$3,0-6,0$ & Sedang \\
$>6,0$ & Besar \\
\hline
\end{tabular}

Sumber: Hunter (2008)

\section{Analisis Data}

Analisis data menggunakan analisis deskriptif kualitatif dan kuantitatif. Parameter analisis kuantitatif berupa nilai retensi, nilai $\mathrm{L}^{*}, a^{*}$ dan $b^{*}$ dan nilai perubahan warna kain katun $(\Delta \mathrm{E})$ yang didapat dari hasil pemindaian menggunakan Flatbed Scanner HP DJ 2135 yang diprogramkan mengunakan software Adobe Photoshop CS 6. Sedangkan parameter analisis kualitatif didapat dari penilaian warna dengan mencocokan pada Munsell Soil Color Chart (2000).

\section{HASIL DAN PEMBAHASAN}

\section{Kadar dan Kandungan Ekstrak}

Hasil penelitian menunjukan proses ekstraksi serbuk buah Rhizophora mucronata dengan metode ekstraksi panas meng gunakan pelarut aquades menghasilkan ekstrak berwarna coklat tua dengan kadar ekstrak sebesar 26,74\%. Lestari dan Pari (1990) menyatakan bahwa kadar ekstrak tergolong tinggi jika lebih dari $4 \%$. Menurut Ahadi, (2003) umumnya senyawa tanin larut dalam air (polar) dan memberikan warna merah gelap atau coklat. Sedangkan menurut Paryanto dkk, (2014) ekstrak buah R.mucronata mempunyai panjang gelombang 600-700 nm yang mempunyai rentang warna coklat tua. Ekstrak buah R.mucronata selanjutnya diuji fitokimia untuk mengetahui kandungan dari bahan aktif yang terdapat di dalam esktrak. Pengujian dilakukan dengan menggunaka reagen Mayer, Wagner dan Dragenfroff untuk mendeteksi kandungan senyawa alkaloid di dalam esktrak. Kemudian dilakukan pengujian untuk mendeteksi kandungan senyawa flavonoid, terpenoid, steroid, fenolik dan saponin. Hasil pengujian fitokimia disajikan pada Tabel 2.

Tabel 2. Uji fitokimia buah Rhizophora mucronata (Phytochemical of Rhizophora mucronata fruit)

\begin{tabular}{|c|c|c|c|c|c|c|c|c|}
\hline \multirow{2}{*}{$\begin{array}{c}\text { Parameter } \\
\text { Uji }\end{array}$} & \multicolumn{3}{|c|}{ Alkaloid } & Flavonoid & Terpenoid & Steroid & Fenolik & Saponin \\
\hline & Mayer & Wagner & Dragendroff & \multirow{2}{*}{+++} & \multirow[b]{2}{*}{+++} & \multirow[b]{2}{*}{-} & \multirow[b]{2}{*}{+++} & \multirow[b]{2}{*}{+} \\
\hline Hasil & +++ & +++ & +++ & & & & & \\
\hline
\end{tabular}

Keterangan: $(-)=$ tidak terdeteksi, $(+)=$ positif lemah, $(++)=$ positif, $(+++)=$ positif kuat

Hasil uji fitokimia pada Tabel. 2 menunjukkan senyawa yang terdapat pada ekstrak buah $R$. mucronata adalah senyawa tanin yang terkandung dalam senyawa fenolik dengan nilai positif tiga $(+++)$. Nilai positif tiga menunjuk 
kan kandungan senyawa yang sangat kuat. Ekstrak buah $R$. mucronata mengandung senyawa alkaloid, flavonoid, terpenoid, dan fenolik, sedikit saponin dan tidak mengandung senyawa steroid. Menurut penelitian Puspitasari, dkk (2012) kandungan metabolit sekunder R.mucronata mengandung senyawa tanin, alkaloid, flavanoid, terpenoid dan saponin. Berdasarkan penelitian Kwartiningsih, dkk., (2014), buah R.mucronata mengandung senyawa tanin sebesar $0,4326 \%$. Senyawa tanin merupakan senyawa fenolik yang mempunyai rasa sepat, mempunyai kemampuan menyamak kulit dan dapat dimanfaatkan sebagai pewarna alami pada tekstil (Mukhlis, 2008).

\section{Pewarnaan kain}

Katun sebelum diwarnai berwarna Light Bluish Gray (Munsell, 2000), setelah diwarnai dengan ekstrak buah R.mucronata berubah menjadi warna Pink (Gambar 2) Warna kain katun sebelum dan sesudah pewarnaan, menunjukkan perubahan yang berbeda. Hal ini didukung dari penilaian kuantitatif dari nilai $L^{*}, a^{*}$ dan $b^{*}$. Nilai $\mathrm{L}^{*}$ (tingkat kecerahan) kain katun sebelum pewarnaan sebesar 98,63 setelah diwarnai nilai nya menurun menjadi 60,28 . Semakin kecil nilai $\mathrm{L}^{*}$ (< 70) maka warna semakin gelap, sedangkan semakin besar nilai $\mathrm{L}^{*}$, maka warna semakin terang. Hal ini berarti bahwa cahaya pantul yang dihasilkan warna akromatik lebih gelap (Hunter, 2008). Nilai $a^{*}$ dan $b^{*}$ setelah pemberian bahan pewarna alam berturut-turut naik menjadi 8,83 dan 9,79 dibandingkan nilai $a^{*}$ dan $b^{*}$ sebelum diberikan bahan pewarna alam berturut-turut yaitu 0,69 dan $(-0,92)$ (Gambar 3). Nilai $a^{*}$ dan $b^{*}$ yang positif ini menandakan bahwa warna pink merupakan kombinasi warna merah dengan kuning. Menurunnya nilai $\mathrm{L}^{*}$ dan bertambahnya nilai $\mathrm{a}^{*}$ dan $\mathrm{b}^{*}$ setelah pewarnaan menunjukan terjadinya perubahan warna menjadi gelap. Sedangkan nilai rerata $\Delta \mathrm{E}$ kain katun setelah diwarnai adalah 22,74. Warna kain katun sebelum dan sesudah diwarnai disajikan pada Gambar 2.

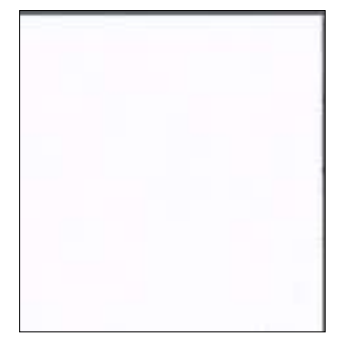

(a)

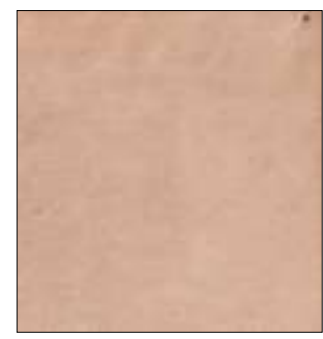

(b)

Gambar 2. Perubahan warna kain katun sebelum dan sesuad diwarnai dengan ekstrak buah Rhizophora mucronata Lamk (a) kain katun sebelum diwarnai (Light Bluish Gray), (b) kain katun setelah diwarnai (Pink) (The change of cotton color before and after coloring with natural dye from extract of fruit Rhizophora mucronata Lamk (a) cotton color before coloring (Light Bluish Gray), (b) cotton color after coloring (Pink) 
Berdasarkan nilai pada Tabel 1 pengaruh perubahan $\Delta \mathrm{E}$ (Hunter 2008) perubahan yang terjadi termasuk kategori besar (>6). Hal ini diduga karena adanya interaksi senyawa yang terkandung di dalam bahan pewarna alami dengan serat kain katun, yang didukung nilai retensi bahan pewarna sebesar $4,47 \mathrm{~g} / \mathrm{cm}^{3}$. Selain dipengaruhi oleh zat pewarna yang ada pada ekstrak, pengaruh perubahan warna pada kain katun juga dipengaruhi oleh sifat kain katun itu sendiri. Kain katun memiliki sifat fisik berupa higroskopis dan sifat kimia yang memiliki senyawa selulosa dengan kandungan $94 \%$ cenderung lebih mudah untuk dimasuki bahan pewarna, karena morfologi serat kain katun jika dilihat menggunakan mikroskop memiliki penampang membujur seperti pita yang terpilin dan penampang melintang seperti ginjal dengan lubang ditengah yang disebut lumen memudahkan terjadinya penyerapan antara bahan pewarna alam dan serat kain katun (Noerati dkk., 2013).

Selanjutnya bahan pewarna alami dari ekstrak buah $R$. mucronata ditambah bahan fiksasi berupa tunjung, kapur dan tawas. Setelah diberi bahan fiksasi, kain katun yang telah diwarnai dicelupkan ke dalam bahan pewarna yang telah diberi bahan fiksasi. Hasil pewarnaan menunjukkan adanya perubahan warna pada kain katun. Penilaian kualitas warna secara kuantitatif dilakukan menggunakan nilai $\mathrm{L}^{*}, \mathrm{a}^{*}$ dan $\mathrm{b}^{*}$ pada ruang warna CIELab. Hasil perhitungan perubahan nilai kualitas warna disajikan pada Gambar 3.

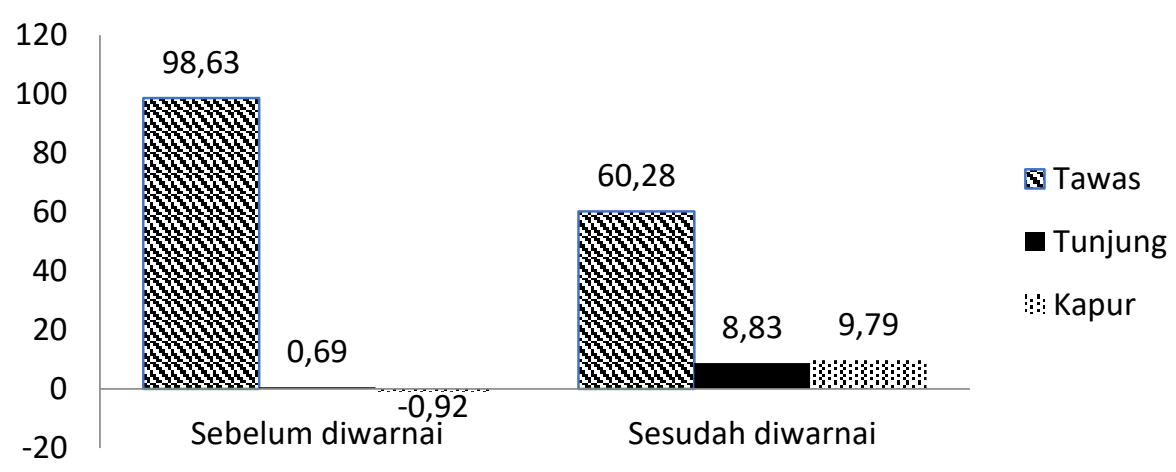

Gambar 3. Nilai Rerata $\mathrm{L}^{*}, a^{*}$ dan $\mathrm{b}^{*}$ pada kain katun sebelum pewarnaan dan setelah pewarnaan dengan ekstrak buah Rhizophora mucronata Lamk yang ditambahkan bahan fiksasi tawas, tunjung dan kapur (The average value of $L^{*}, a^{*}$ and $b^{*}$ before and after coloring with natural dye extract from fruit of Rhizophora mucronata Lamk with additional of fixation material of tawas, tunjung and kapur )

\section{Fiksasi kain katun}

Proses pewarnaan bahan tekstil dengan pewarna alam dibutuhkan proses fiksasi yaitu proses penguncian warna setelah bahan direndam dengan pewarna alam agar warna memiliki 
ketahanan luntur yang baik (Fitrihana, 2007). Hasil fiksasi pada kain katun yang terwarnai untuk semua jenis bahan fiksasi menghasilkan warna yang bervariasi, dengan pengaruh perbedaan nilai $\Delta \mathrm{E}>6,0$ (besar). Perubahan warna terbesar $(\Delta \mathrm{E})$ terjadi pada kain yang difiksasi menggunakan tunjung dan kapur. Perubahan warna terkecil terjadi pada kain yang difiksasi menggunakan tawas. Perbedaan warna $(\Delta \mathrm{E})$ disebabkan oleh sifat dasar bahan fiksasi yang digunakan. Nilai perubahan warna kain setelah difiksasi dengan bahan tunjung, kapur dan tawas disajikan pada Gambar 4.

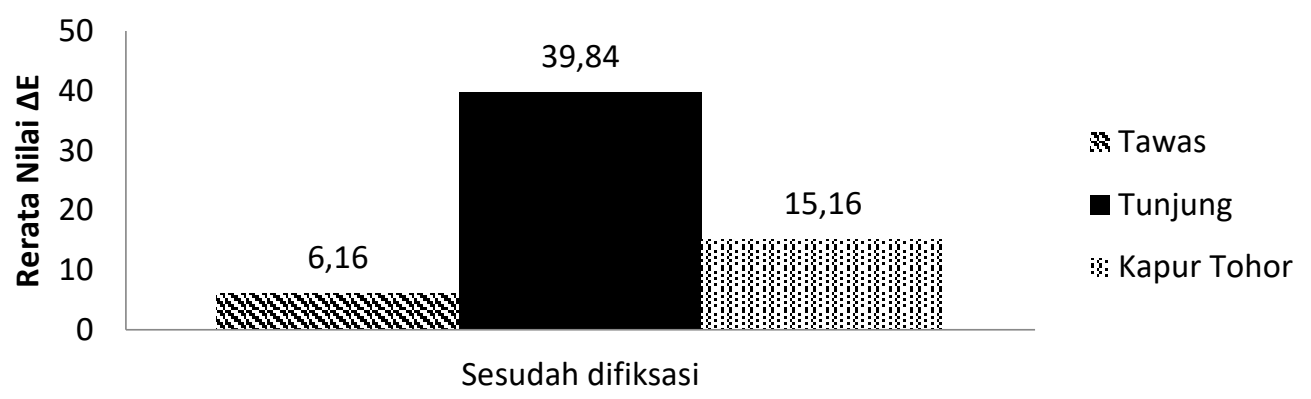

Gambar 4. Nilai rerata $\Delta \mathrm{E}$ kain katun setelah pewarnaan dengan ekstrak buah Rhizophora mucronata Lamk yang ditambahkan bahan fiksasi tawas, tunjung dan kapur (The average value of $\Delta E$ cotton after coloring with natural dye extract from fruit of Rhizophora mucronata Lamk with additional of fixation material of tawas, tunjung and kapur )

\section{Perubahan Warna Kain}

Hasil pengamatan warna setelah difiksasi menggunakan tiga bahan fiksasi yang berbeda yaitu tawas, tunjung dan kapur tohor menunjukan adanya perubahan warna yang berbeda pula (Gambar 5). Warna kain yang dihasilkan dari fiksasi tawas menunjukan tidak adanya perubahan warna antara sebelum difiksasi dan sesudah difiksasi yaitu Pink (Tabel 3). Walaupun hasil Munsell Soil Color Chart tidak menujukan perubahan warna, namun hasil pengukuran dengan menggunakan metode CIE Lab menunjukan terdapat perubahan nilai $\mathrm{L}^{*}, a^{*}$ dan $\mathrm{b}^{*}$. Nilai $\mathrm{L}^{*}$ mengalami kenaikan dari 74,48 menjadi 77,99, hal ini menunjukan warna yang dihasilkan menjadi lebih terang. Selanjutnya, nilai $a^{*}$ (kombinasi merah dan hijau) dan $\mathrm{b}^{*}$ (kombinasi kuning dan biru) mengalami penurunan berturut-turut dari 11,56 menjadi 9,15 dan dari 17,49 menjadi 15,08 , hal ini berarti bahwa warna yang dihasilkan menjadi lebih terang. Kenaikan nilai $\mathrm{L}^{*}$ dan penurunan nilai $a^{*}$ dan $b^{*}$ diduga dipengaruhi oleh kandungan senyawa kimia yang terdapat dalam bahan fiksasi yaitu $\mathrm{Al}^{3+}$ dari larutan tawas yang bereaksi dengan pewarna alam menghasilkan warna lebih terang (Ruwana, 2008). 


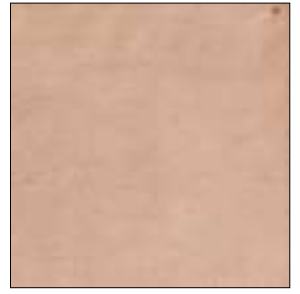

(a)

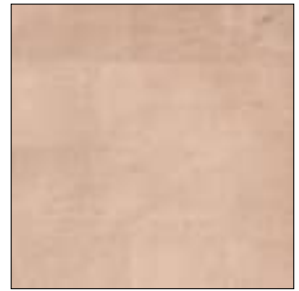

(b)

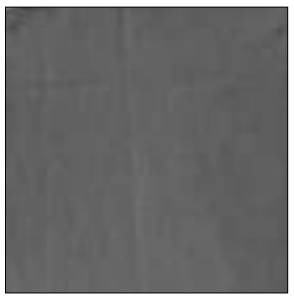

(c)

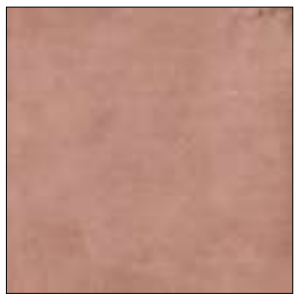

(d)

Gambar 5. Perubahan warna kain katun yang diwarnai dengan ekstrak buah Rhizophora mucronata Lamk (a) Warna kain katun setelah diwarnai esktrak buah Rhizophora mucronata Lamk tanpa bahan fiksasi, (b) Warna kain katun setelah difiksasi tawas, (c) Warna kain setelah difiksasi tunjung, (d) Warna kain setelah difiksasi kapur tohor (The change of color of cotton after coloring with extract of fruit of Rhizophora mucronata Lamk (a) Color of cotton after coloring with extract from fruit of Rhizophora mucronata Lamk without additional of fixation material, (b) color of cotton after fixation of tawas, (c) color of cotton after fixation of tunjung $/ \mathrm{FeSO}_{4}$, (d) Color of cotton after fixation of kapur tohor).

Warna kain yang dihasilkan dari fiksasi tunjung menunjukan adanya perubahan warna yaitu dari cerah (Pink) menjadi gelap (Dark Gray). Hasil pengukuran warna yang diukur dengan metode CIELab terdapat perubahan nilai $\mathrm{L}^{*}, a^{*}$ dan $\mathrm{b}^{*}$. Nilai $\mathrm{L}^{*}$ mengalami penurunan dari 74,02 menjadi 40,32, sedangkan nilai $a^{*}$ dan $b^{*}$ mengalami penurunan berturut-turut dari 12,04 menjadi 0,00 dan dari 18,43 menjadi 0,00 . Perubahan warna ini diduga karena adanya pengaruh kandungan senyawa kimia $\mathrm{Fe}^{2+}$ yang terdapat dalam tunjung $\left(\mathrm{FeSO}_{4}\right)$ membentuk garam kompleks yang membuat warna menjadi lebih gelap (Ruwana, 2008).

Warna kain yang dihasilkan dari fiksasi kapur tohor menunjukan adanya perubahan warna kain yaitu dari Pink menjadi Light Reddish. Hasil pengukur an warna yang diukur dengan metode CIELab menunjukan adanya penurunan nilai $L^{*}$ dari 75,98 menjadi 62,53 dan nilai $b^{*}$ dari 16,81 menjadi 14,29, sedangkan nilai $a^{*}$ mengalami kenaikan dari 11,10 menjadi 17,32 . Hal ini menyebabkan perubahan warna kain setelah difiksasi menjadi lebih kemerahan. Perubahan warna ini diduga karena pengaruh kandungan senyawa kimia yang terdapat dalam bahan fiksasi yaitu, $\mathrm{Ca}^{2+}$ dari larutan kapur yang terjadi reaksi antara bahan pewarna alam dengan $\mathrm{Ca}^{2+}$ (Ruwana, 2008). Menurut Pulungan (2016), jenis fiksasi mempunyai pengaruh terhadap ketuaan warna, diantara ketiga jenis bahan fiksasi tersebut, tunjung dan kapur tohor memiliki kemampuan untuk menuakan warna, sedangkan tawas memudakan warna. Pengaruh dari penambahan bahan fiksasi dapat meningkatkan melekatnya bahan pewarna alam pada permukaan serat dan menghasilkan warna yang lebih kuat serta warna yang berbeda pada masing-masing bahan fiksasi (Ruwana, 2008). 
Tabel 3. Perubahan warna dan nilai rerata $\mathrm{L}^{*}, a^{*}$ dan $\mathrm{b}^{*}$ kain katun yang telah diwarnai dengan ekstrak buah Rhizophora mucronata Lamk sebelum dan sesudah ditambahkan fiksasi dengan bahan tawas, tunjung dan kapur tohor (The change of color of cotton and average value of $L^{*}, a^{*}$ and $b^{*}$ of cotton after coloring with extract of fruit Rhizophora mucronata Lamk before and after additional with fixation material with tawas, tunjung and kapur tohor)

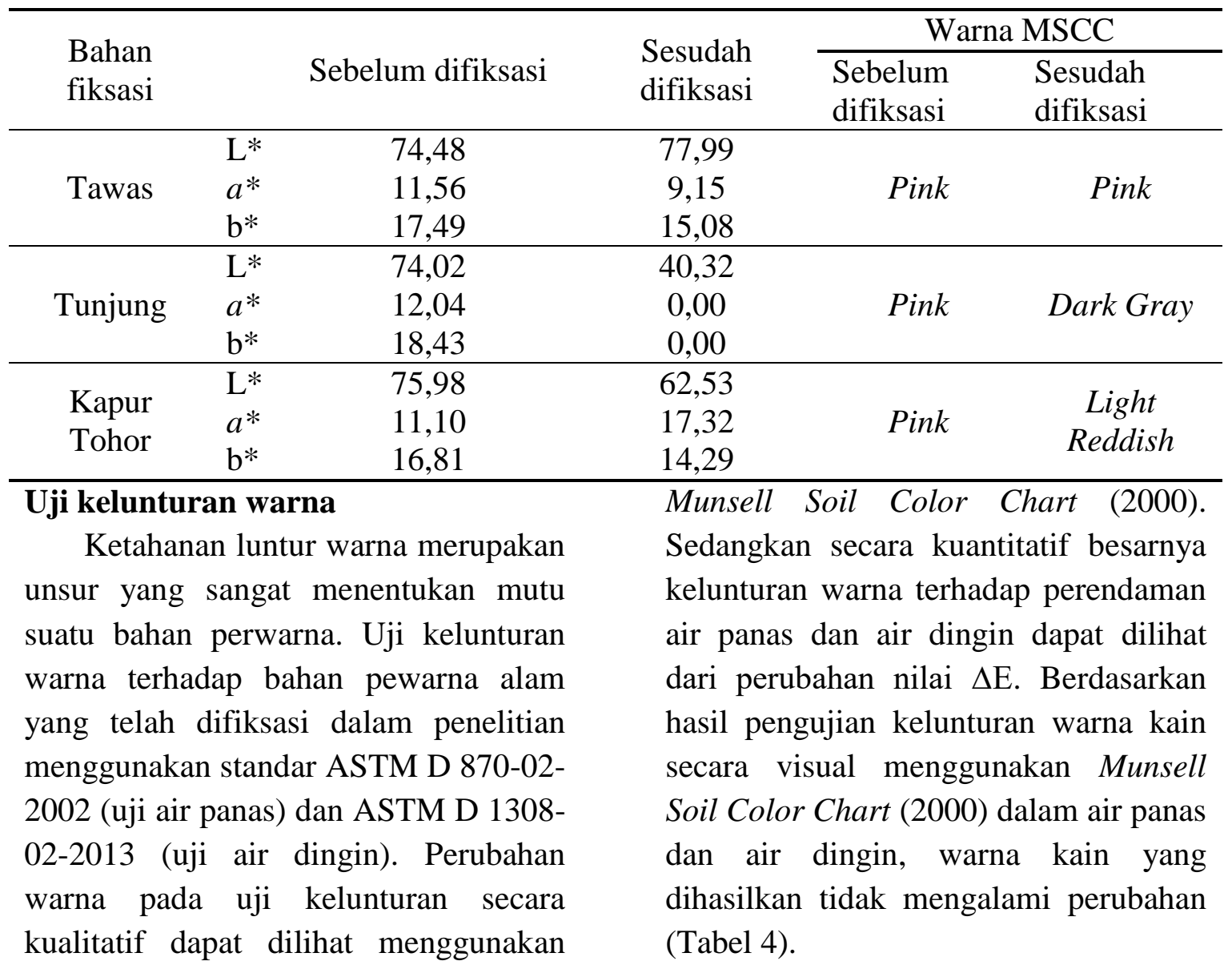


JURNAL TENGKAWANG (2019)

Vol. 9 (1) : 1 - 13

Tabel 4. Warna kain katun sebelum dan sesudah uji luntur pada air panas dan air dingin (The color of the cotton cloth before and after the testwears off in hot and cold water)

\begin{tabular}{cccc}
\hline Bahan Fiksasi & Tawas & Tunjung & Kapur Tohor \\
\hline Sebelum Uji Luntur & & & \\
& & \\
Uji Luntur Air Panas & Pink & Dark Gray & Light Reddish \\
& & \\
Uji Luntur Air Dingin & Pink & Dark Gray \\
& & \\
& & Dark Gray Reddish \\
& Pink &
\end{tabular}

Berdasarkan nilai $\Delta \mathrm{E}($ Gambar 6) hasil uji ketahanan luntur dalam air panas dan dingin menunjukkan perubahan nilai yang kecil hingga sedang (kisaran $\Delta \mathrm{E}$ 2,42-3,73). Nilai $\Delta \mathrm{E}$ terbesar didapat dari kain yang di uji kelunturan pada air panas dan kain yang difiksasi menggunakan kapur tohor. Perubahan nilai $\Delta \mathrm{E}$ menunjukan besarnya nilai kelunturan warna. Semakin tinggi nilai $\Delta \mathrm{E}$ maka kelunturan semakin besar dan semakin rendah nilai $\Delta \mathrm{E}$ maka kelunturan semakin kecil. Kelunturan tertinggi terjadi pada kain yang diuji luntur dalam air panas dengan bahan fiksasi kapur tohor. Hal ini diduga bahwa air panas memiliki kemampuan menarik bahan pewarna alam yang terfiksasi lebih kuat pada serat kain dibandingkan air dingin. Hal yang sama juga dilakukan Ruwana (2008) yang menguji kelunturan tiga jenis kain yang diwarnai dengan ekstrak kulit batang kayu jati menunjukan kelunturan tertinggi dihasilkan pada kain yang diuji kelunturan dengan air panas. Uji luntur terhadap air panas dapat mempertinggi kelarutan zat warna, memperbesar penggelembungan pori-pori serat, membuat serat menjadi plastis, mempercepat daya difusi zat warna ke dalam serat (Sunaryo, 1974).

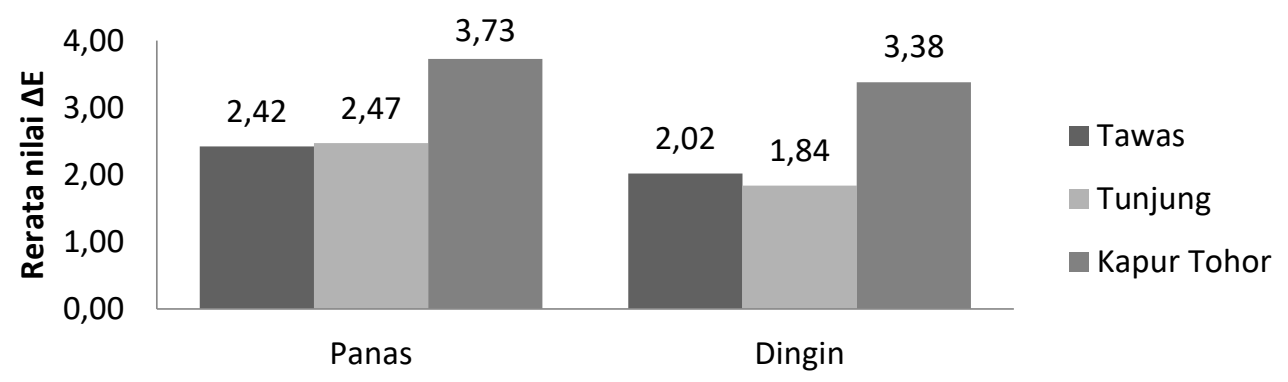

Gambar 6. Perbandingan rerata nilai $\Delta \mathrm{E}$ setelah uji luntur air panas dan air dingin (Average ratio of $\Delta \mathrm{Evalues}$ after the hot and cold water fastness test) 
Selain pengaruh pemanasan, nilai kelunturan juga diduga dipengaruhi oleh bahan fiksasi yang berhubungan dengan kuat lemahnya ikatan antar serat dan bahan pewarna alam yang terfiksasi. Ruwana (2008) menyatakan bahwa reaksi bahan fiksasi kapur tohor tidak menghasilkan garam, maka ikatan antara serat kain dan senyawa yang mengikatnya kurang kuat, akan tetapi memiliki senyawa-senyawa yang berikatan ionik sehingga menyebabkan tingkat kelunturan tinggi. Penggunaan air dingin dalam uji luntur warna memiliki tingkat kelunturan lebih rendah dibandingkan dengan air panas. Artinya, penggunaan air dingin untuk pencucian kain katun terwarnai bahan pewarna alam lebih baik daripada menggunakan air panas.

\section{Kesimpulan}

1. Buah Rhizophora mucronata Lamk yang diekstrak menggunakan aquades menghasilkan kadar ekstrak sebesar 26,74\% dengan warna ekstrak coklat tua.

2. Ekstrak buah Rhizophora mucronata dapat mewarnai kain katun dengan warna yang dihasilkan ialah pink, dengan nilai rerata retensi sebesar $4,47 \mathrm{~g} / \mathrm{cm}^{3}$.

3. Penambahan bahan fiksasi tunjung dan kapur tohor menghasilkan warna yang lebih tua (gelap) pada kain katun, sedangkan fiksasi tawas membuat kain katun yang telah diwarnai menjadi lebih cerah.

4. Kelunturan tertinggi terjadi pada kain katun dengan bahan fiksasi kapur tohor pada uji kelunturan pada air panas.

5. Buah Rhizophora mucronata Lamk berpotensi sebagai bahan pewarna alami dan penambahan bahan fiksasi tunjung dapat memperkuat daya tahan warna serta menghasil kan warna yang lebih gelap sehingga cocok dalam industri perkayuan.

\section{Saran}

Kain katun yang diwarnai menggunakan pewarna alam dari buah Rhizophora mucronata sebaiknya dicuci dengan menggunakan air dingin untuk menghindari kelunturan yang besar. Kemudian disarankan untuk dilakukan penelitian lebih lanjut mengenai kelunturan warna terhadap sabun, penggosokan dan keringat.

\section{DAFTAR PUSTAKA}

Ahadi, M. R. 2003. Kandungan Tanin Terkondensasi dan Laju Dekom posisi pada Serasah Daun Rhizophora mucronata Lamk pada Ekosistem Tambak Tumpangsari, Purwakarta, Jawa Barat. Institut Pertanian Bogor, Bogor.

American Society for Testing and Materials. 2000. [ASTM] Standar Test Method for Evaluation of Painted or Coated Specimens Subjected To Corrosive Environ ments. ASTM D 870-02.

American Society for Testing and Materials. 2013. [ASTM] Standar Test Method for Effect of House hold Chemicals on Clear and Pigmented Organic Finishes. ASTM 1308-02. 
Badan Lingkungan Hidup Kota Singkawang. 2015. Calon Penerima Penghargaan Lingkung an Hidup Nasional Kalpataru Tahun 2014 dengan Kategori Penyelamat Lingkungan. Kota Singkawang.

Fitrihana, N. 2007. Teknik Eksplorasi Zat Pewarna Alam dari Tanaman di Sekitar Kita untuk Pencelupan Bahan Tekstil. [diakses 28 Juni 2018]. http://batikyogya.wordpress.com

Hunter Lab. 2008. Hunter Lab Color Scale. www.hunterlab.com

Kwartiningsih, E., Paryanto, Wibowo, W.A., Masturi, E., Jati, A.K., dan Santoso, D.P. 2013.Ekstraksi Tanin dari Buah Mangrove (Rhizophora mucronata). Prosiding Simposium RAPI XII, Fakultas Teknik UMS. No. ISSN 1412-9612.

Lailia, Kumalaningsih S, dan Effendi M. 2014. Ekstraksi Pewarna Alami Dari Daun Jati (Tectona grandis): Kajian Konsentrasi Asam Sitrat dan Lama Ekstraksi dan Analisa Tekno-Ekonomi Skala Laboratorium. Jurnal Teknologi dan Manajemen Agroindustri, (3): 1.

Lestari, S.B., Pari G. 1987, Analisis Kimia Beberapa Jenis Kayu Indonesia. Jurnal Penelitian Hasil Hutan 7:96-100.

Muflihati, Nawawi D.S, Rahayu I.S, Syafii W. 2014. Perubahan Warna Kayu Jabon Terwarnai Ekstrak Kulit Kayu Samak (Syzygium inophyllum). Jurnal Ilmu dan Teknologi Kayu Tropis 12(1): 1119

Mukhlis. 2008. Ekstraksi Zat Warna Alami Dari Kulit Batang Jamblang (Syzygium cumini)
Sebagai Bahan Dasar Pewarna Tekstil. Fakultas Pendidikan Kimia. Universitas Unsyiah Darussalam Banda Aceh.

Munsell. 2000. Munsell Soil Color Charts (Year 2000 Revised Washable Edition). Gretagmacbeth. : Munsell Color Company- x-rite.

Paryanto, Kwartiningsih E, Wusana A.W, Sunu H P,Haningtyas V, Hidayat R, Ilham Roy S. 2015. Pengambilan Zat Warna Alami dari Buah Mangrove Spesies Rhizophora Mucronata untuk Pewarna Batik Ramah Lingkungan. Jurnal Purifikasi, (15): 1 .

Pulungan, Maimunah H., Selfi D.A, Wignyanto, Saundra R. L. 2016. Pewarna Alami Daun Sirsak (Annona muricata L.) untuk Kain Mori Primissima (Kajian: Jenis dan Konsentrasi Fiksasi). Jurnal Tekno logi dan Manajemen Agroindustri 5(3): 132-139

Ruwana, I., 2008. Pengaruh Zat Fiksasi Terhadap Ketahanan Luntur Warna Pada Proses Pencelupan Kain Kapas Dengan Menggunakan Zat Warna Dari Limbah Kayu Jati (Tectona grandis). 31(1): Universitas Negeri Semarang.

Suheryanto, D. 2013.Eksplorasi Pembuatan Zat Warna Alam dalam Bentuk Pasta dengan Teknik Evaporasi.Yogyakarta: Balai Besar Kerajinan dan Batik, Badan Pengkajian Kebijakan Iklim dan Mutu Industri, Kementerian Perindustrian.

Sunaryo. 1974. Proses Pengerjaan Kain Campuran Poliester Kapas. Bandung: Institut Teknologi Tekstil 